2001

\title{
Of Bulldogs and Soapy Sams: The Common Law and Evolutionary Theory
}

Allan C. Hutchinson

Osgoode Hall Law School of York University, ahutchinson@osgoode.yorku.ca

Simon Archer

Follow this and additional works at: http://digitalcommons.osgoode.yorku.ca/scholarly_works

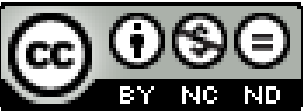

This work is licensed under a Creative Commons Attribution-Noncommercial-No Derivative Works 4.0 License.

\section{Recommended Citation}

Hutchinson, Allan C., and Simon Archer. "Of Bulldogs and Soapy Sams: The Common Law and Evolutionary Theory." Current Legal Problems 54 (2001): 19-59.

This Article is brought to you for free and open access by the Faculty Scholarship at Osgoode Digital Commons. It has been accepted for inclusion in Articles \& Book Chapters by an authorized administrator of Osgoode Digital Commons. 


\title{
OF BULLDOGS AND SOAPY SAMS: THE COMMON LAW AND EVOLUTIONARY THEORY
}

\author{
Allan C. Hutchinson and Simon Archer ${ }^{*}$
}

Ronald Dworkin: '[Pragmatism] is philosophically a dog's dinner.' Richard Posner: 'I take it [Dworkin] does not much like dogs.' Ronald Dworkin: 'As it happens, I like dogs very much.'

Richard Posner: 'As a cat person, I am disappointed. I hope I will be forgiven for having thought him distinctly feline.'1

The venue-the annual meeting of the British Association for the Advancement of Science in Oxford's newly built Museum of Natural History-and the occasion-a lecture on European social development by a relatively unknown American scholar, Dr John William Draper-were fairly unremarkable. But the unscheduled debate that followed, although much anticipated by the unprecedented and eminent 700 in attendance, has become the fabled stuff of historical moment. Occurring on Saturday 30 June 1860 , only six months after the publication of Charles Darwin's On The Origin of Species, the face-off over the controversial theory of evolution by natural selection was between the conservative and sceptical Bishop of Oxford, 'Soapy Sam' Wilberforce, and the uncompromising scientist and leading public intellectual of the day, Thomas Henry 'Bulldog' Huxley. While the topic was supposed to be the subtle scientific implications of Darwin's evolutionary account, the agenda was much broader and more polarized; it pitted the established church order against an emerging scientific new wave. In so doing, this Victorian debate set the tone and terms for lengthy intellectual debate about evolution and much more over the next century and a half. For all its imputed sophistication and scholarliness, parts of contemporary jurisprudence

\footnotetext{
We are grateful to Joanne Conaghan, Michael Freeman, William Lucy, and Derek Morgan for their critical comments and helpful suggestions.
} 
have come to exhibit the melodramatic and vindictive quality of that famous Oxford debate. Ronald Dworkin and Richard Posner's recent exchanges not only resonate with similar tart rhetoric, but their substantive positions have uncanny resemblances to those of Soapy Sam and the Bulldog.

Those resemblances can be found in their respective positions within the 'evolutionary paradigm' for explaining the development of the common law. This paradigm has a 200-year history in accounts of common law traditions and development, and has become increasingly sophisticated in the past twenty-five years. We have picked out Dworkin and Posner because they have well known and perhaps representative views for two common positions within this paradigm, but the offerings are rich for those with an interest in subspecies, precursors, and filiation. We will assess one of the deeper jurisprudential differences that separate Dworkin and Posner: their respective stances on the tradition of the common law, especially its operation and development. While on the face of it both sides view the legal process and adjudication as distinctly human enterprises, they disagree profoundly over whether this enterprise is better understood in the philosophical cast of natural law or in the social-scientific terminology of 'efficient' decision-making. Whereas Dworkin insists that law must be understood as a site for abstract and coherent reflection on the moral basis of the good society, Posner contends that law is less about theory and more about facts in that judges should do whatever is most useful in the particular social circumstances. It is presented as a case of the soapy moralist against the bulldoggish pragmatist. For one, adjudication is being driven by some moral force that is much bigger and better than any single judge; for the other, the judge is an adaptionist agent for society's struggle for survival. However, on closer inspection neither combatant's position is quite what it appears to be. Both Dworkin and Posner have, if you will, a Creationist flavour, in that they each fall 
back on the discredited idea that there is one particular truth to law that does or should transcend all others and that there is one method for elucidating and perpetuating that truth.

Whatever the differences between Dworkin and Posner, we suggest that both they and a good portion of theorizing on evolution-and-law employ that paradigm at serious risk to their projects, because in our reading they import a contradiction central to their propositions through the analogy to evolutionary theory. This is that, even if change in the common law occurs through some sort of natural selection akin to that proposed by Darwinian evolution, the mechanism by which change operates in evolutionary theory, the transmission of genetic material, has been characterized as chance-like, random, or even the site of 'mistakes' in replication. We suspect that this insight from evolution is not central to either Dworkin's nor Posner's views on common law. But we do contend that any analogy to evolution must cope with this particular aspect of that analogy, as being one of two core elements that describe and explain change and development. Perhaps in reaction to this threat, writers within the evolution and law paradigm have generated a number of much more sophisticated responses or amendments to the basic analogy employed or implied by Posner and Dworkin. Part of this chapter traces attempts to cope with exactly that sort of indeterminacy in open systems.

But our dominant ambition in this paper is to flush out the lingering theological traces that clog up Dworkin's approach and that also pushes through on the pragmatic aspirations of Posner's initiative. In short, we wish to clarify the political implications of much of the evolution-as-law paradigm through a comparison of Posner and Dworkin's place within it. While Posner is correct to chastise Dworkin for the divine intimations of his philosophical theorizing, he fails to heed the radical import of his own pragmatic critique. Similarly, 
although Dworkin is correct to come down hard on Posner for the disingenuous modesty of his pragmatic perspective, he wastes the opportunity to put his own abstract house into working order. Our intervention seeks to demonstrate law's pragmatic character at the same time that it confirms adjudication's political quality. We also spend time discussing some aspects and history of evolutionary theory as it pertains to our argument. As such, this paper is divided into five parts. In the first part we sketch the initial terms of engagement over Darwin in the scientific community; the emphasis is on mapping the territory, not on mining it, and on suggesting the components of a common-that is non-specialist discourse of evolution. The second section explores the different ways in which the evolutionary insight has found its way into legal studies and associated claims to enhance an appreciation of law's historical development. In the third section we focus on the contributions of Dworkin and Posner around the relevance of evolutionary thinking to law; the point is to show, not so much that they are of little value, for they are not, but that they overreach themselves in making the claims that they do. In the final section we make modest proposals for the construction of legal traditions, their change and development. Throughout the essay, as well as confining ourselves to a largely descriptive brief, we emphasize that the jurisprudential challenge is more to explain change than to explain stability and that no change is good or bad in itself, but will depend on the context. By way of conclusion we recognize that, when it comes to law and adjudication, evolution is as much a responsibility as it is a necessity.

Terms of Engagement

After Draper's lacklustre and forgettable lecture on 'The Intellectual Development of 
Europe Considered with Reference to the Views of Mr. Darwin', Bishop Wilberforce took the floor. As expected, he gave a powerful, if over-wrought renunciation of Darwin's theory; he was not known as Soapy Sam for nothing. Briefed by Robert Owen, one of Darwin's fiercest scientific critics, he lambasted the evolutionary initiative and restated the Creationist case. Echoing the words of his yet-to-bepublished review of the Origin, Wilberforce made sport with Darwin and his earnest defenders. After noting Darwin's apparent observations about 'our unsuspected cousinship with mushrooms', he asked 'is it credible that, even if transmutations were rapidly occurring, all favourable varieties of turnips are tending to become men?'2 At the end of his rather bombastic harangue, Wilberforce turned to Huxley, who was sitting close by him, and said 'I should like to ask Professor Huxley who is about to tear me to pieces when I sit down, as to his belief in being descended from an ape. Is it on his grandfather's or his grandmother's side that the ape ancestry comes in?' As Huxley stood up to speak the tension was high. But the normally snappy and high-strung Huxley managed to muzzle his bulldog tendencies. Turning to his neighbour, Sir Benjamin Brodie, the Queen's surgeon, he whispered 'the Lord have delivered him into my hands'.

In a deft stroke of gamesmanship, Huxley replied: 'I should feel it no shame to have risen from such an origin, but I should feel it a shame to have sprung from one who prostituted the gifts of culture and eloquence to the service of prejudice and falsehood.' At the time, this was strong stuff and a member of the audience, Lady Brewster, fainted at hearing a Bishop so publicly denounced. But the debate was not finished. Several noted members of the audience rose to speak, including a bible-brandishing Robert Fitzroy, Darwin's former friend and captain of the Beagle ship on which Darwin had made his fateful trip some thirty years before, who denounced Darwin as a heretic and an apostate. The final speaker was Joseph Hooker, the Director of the Royal Botanical Gardens 
at Kew; he had his own political as well as scientific reasons for championing the Darwinian cause. In contrast to the fevered interventions that preceded his, Hooker wisely made a less emotional and more learned riposte to Wilberforce's assault. Although less memorable than Huxley's verbal fireworks, his hard-hitting arguments against Wilberforce probably did more for the longer term benefit of the Darwinian cause: 'facts in this science which before were inexplicable to me became one by one explained by [Darwin's] theory, and conviction has been thus gradually forced upon an unwilling convert.'3

By most accounts, a rampant Huxley and the scientific academy won the day over a chagrined Wilberforce and his clerical enthusiasts. However, as the intervening decades have revealed, Creationism is not so easily vanquished. Moreover, the 'scientific cause' has not always been helped by the fact that many of those who claim to be inspired by Darwin's work have pursued their own supposedly secular theories with an orthodox zeal that would embarrass all but the most devoted cleric. In the hands of such evolutionary fundamentalists, Darwinism becomes 'a world view that encompasses the hierarchically related concepts of change, order, direction, progress, and perfectability'. ${ }^{4}$ However, as the Oxford quarrel suggests, there is much more at stake in discussing Darwin than a recherche biological theorem. Whatever else it is, science is never only science, and the difference between science and other pursuits is much less stark than is generally conceded: 'the negotiations [between working scientists] as to what counts as a proof or what constitutes a good assay are no more or less orderly than any argument between lawyers and politicians.' 5 In the case of Darwin, the stakes are so high because it provides some propositions about core questions of human existence where did it all begin, how did we get here from there, and 
perhaps even what can we do about the future-and to do so with the authority of a scientific theory. Along with Isaac Newton and Albert Einstein, Darwin is considered one of the greatest scientists ever: his work has not only changed the way that scientists go about their work, but has affected the way people think about the world and their place in it.6 As such, 'Darwin' has come to represent something apart from the historical person and published words of Charles Darwin. Indeed, what Darwin did and did not mean is much less important than what can be said about evolution in the light of Darwin's writings against and within a context of twenty-first-century science and sensibilities.

Nonetheless, insofar as there is something that has come to be called a Darwinian account of evolution, it deserves to be distinguished and rescued from the spectrum of derivative theoretical offerings that are more Darwinistic than Darwinian. It is tantamount to fundamentalism to claim that something is or is not true simply because Darwin did or did not say it. It is better to view Darwin's theory as a launching pad for various ideas about the phenomenon of change and development in the natural world. As Steve Jones has irreverently put it, 'evolution is a political sofa that molds itself to the buttocks of the last to sit upon it'.7

In the sense of a discourse of evolution that we are constructing, evolution is a variant of the doctrine of progress. It can be traced to the Greeks, of whom Aristotle offered the most compelling ideas about the continuity and developing nature of all living things. In the intervening centuries it appeared in many different incarnations. Yet the common thread to most offerings was that there was some notion of progress at work in which the world was not simply on the move, but was heading towards some sophisticated end-point, be it theological in plan or purpose. Moreover, it was maintained that there was a hierarchical arrangement to nature which placed humans at its apex. By the 
early nineteenth century, when Darwin took his trip on HMS Beagle to the Galapagos Archipelago, the prevailing wisdom among biologists was the Lamarckian notion that individuals adapt to their environment and that those altered characteristics are inherited by that individual's progeny. Darwin took this attractive suggestion and turned it on its head. 8 He got the basic idea in 1838 that: 'in the struggle for existence ... favourable variations would tend to be preserved and unfavourable ones to be destroyed.'9 After over twenty more years of experiment and reflection, Darwin published his revolutionary Origin of Species in 1859. In this attempt to present a 'long catalogue of facts', Darwin's revolutionary contribution was manifold-to suggest how that process worked, how seemingly different species are related, how evolution was not planned or inevitable, and how Homo sapiens was not only related to more primitive life-forms, but also was not the necessary outcome of the evolutionary process. Accordingly, Darwin did not so much introduce the idea of evolution as develop a particular version of evolution and a view on the particular mechanism by which evolution occurs. Conceding that nature had the appearance of being designed by some grand and benevolent hand, he nevertheless demonstrated that the apparent design was the relentless result of chance; a designing deity is displaced by the impression of one that does not actually exist. Although Darwin's work is densely packed with his amassed evidence and supporting argumentation, the central thesis of On The Origin of Species is perhaps simple if entirely innovative. Several ideas are blended together explaining a large pool of data-the fossil record-which combine to suggest a sort of dynamic of evolution. He selects examples on which to hang his argument-leading in quietly, with a discussion of domestication-and manages to construct hypotheses that would explain all examples of evolution, all 'instances' of the fossil record that could be pointed to as 
'proof'. It is a remarkable effect.

When listed, the conceptual building-blocks might run as follows. Organisms create more offspring than can survive. In procreating these offspring, mutations occur, randomly it was suspected, and are as likely to be detrimental as beneficial to the organism, or to be neutral with respect to survival chances. They do not result, as Lamarck had insisted, as a designed function of willed adaptation.10 Those mutated offspring which are able to survive a given environment will have better chances of living to reproduce, and possibly pass along their 'mutuations'. Over time and across populations, these variations will accumulate; new characteristics and even species will develop and some species will disappear. Darwin called this process 'natural selection'. He suspected that there is no predetermined path or design to evolutionary development, but could not know, and developed his argument so as to suggest this. His work makes it clear that he had little tolerance for the view that evolution was either a purifying Platonic process in which variant forms are eliminated so that a species' true being can assert itself or a Panglossian process in which everything happens for the best. Although quantitative change will ultimately result in qualitative difference, evolution is basically the long process through which natural selection works on genetic variations. To say more than this about Darwin's basic evolutionary thesis is to court controversy. But these are, we suggest, the basics of the mainstream appreciation of the theory of evolution. In a twist of historical appreciation, Darwin's work has come to be treated as much more, as having political, ethical, and even religious significance. The struggle to claim the origin and descent of Darwinian evolutionary thought for a particular political, ethical, or religious campaign has gone on unabated.

Legal scholars have never been afraid to join the battle. We have chosen to divide those initiatives and interpretations into three general groups, the 
Darwinians, the Creationists, and the neo-Darwinians, for the purposes of our analysis. The next sections outline the basic positions in evolutionary theory, which are tracked by positions in legal thinking about common law development. Given a little bit of time to acclimatize and update, Bulldog Huxley and Soapy Sam Wilberforce would soon be at home in contemporary debates over the meaning, significance, and reach of evolution. It is Darwin who might be more disturbed at the turn that events have taken, but no less fascinated.

There is a significant group who hold to a fairly traditional understanding of Darwin's ideas. Within this Darwinian camp there are positions that differ on questions left open by Darwin. However, they generally turn on differing emphases in their explanations rather than on fundamental assumptions. There is some division over the pace of evolution: whether evolution proceeds at a steady and gradual rate, or by stages of punctuated equilibrium in which change happens in geologically brief speciation events separated by long periods of stasis, and secondly, on the 'level' at which evolution occurs: the strictly genetic, or the interplay of factors at several levels in the organism's existence.11 This traditional account, with its modern variations or debates, is the well-spring for most analogies between law and evolution and, we suggest, the most ubiquitous metaphor or analogy made in mainstream accounts of common law development.

While there are still those who believe in a Genesis-inspired account of creation, there is a new Creationist approach that seeks to blend science and theology.12 Not only do they assert that evolutionary accounts are wrong because God or some higher being is ultimately the hand behind creation, but also these Creationist scholars argue that Darwinism is unsubstantiated on the facts, ill conceived as scientific method, and mischievously biased. Moreover, mindful that available evidence of events over millions of years is limited and 
impressionistic, they insist that their own approach is as plausible as any other. Exploiting gaps and uncertainties in the fossil record, or the ability of Darwinian models to account for 'irreducibly complex' organisms, they suggest that God is to be found in the details of 'intelligent design' which characterize evolution, and whose purpose and direction is divine but unknowable. We will suggest that a popular view of common law development, perhaps most robustly expressed in ideas of natural law, partakes quite readily of this Creationist discourse. We return to this comparison below.

The second group of dissidents from traditional Darwinism are the neoDarwinians. This motley troop can again be subdivided into so-called social Darwinians and ultra-Darwinians. The former cannot resist putting Darwin's theorizing to prescriptive effect in a wide array of human affairs; the latter want to utilize it to reductionist ends. At their crudest, the social Darwinians persist in claims that poor people are poor because they are less fit or that race or gender are determinative of various social capacities. The unifying goal of these social Darwinians is to offer a prescriptive dimension for future human progress: individual struggle becomes both the engine and the engineer of good social organization. Huxley was eventually to belong to this camp.13 As a normative initiative, it cannot simply be posited as a fact of nature because this assumes what is the major bone of contention in ethical and political inquiry; 'facts' and 'nature' are contested categories. The other neo-Darwinians are the ultra-Darwinians. It is not so much that they disagree over the basic Darwinian thesis or that they see any grand design at work, it is that they wish to extend Darwin's notion of evolution to everything, or perhaps we could say, reduce everything to genetics. (Although we note below that the application is more selective than it appears: this application usually involves an emphasis on 'natural selection'.) In the same way that flora and fauna can be said to thrive as a result of their genes' 'urge' to 
survive, so human behaviour is said to be reducible to a similar dynamic. Bracketing Darwin's rider 'I am convinced that natural selection has been the main but not the exclusive means of modification', 14 they claim that, whereas the gene is the basic unit of evolution and the population at large are disposable vehicles for its survival, an entity called a meme fulfils a similar role for ideas and concepts. 15 It gets accused, in the main, of being a 'vulgar reductionism' of human affairs. As one commentator has neatly put it, 'even if you can build a bottle from which the desired genie emerges, you can't reduce the genie to the bottle once it's out'.16 This cautionary insight has particular salience for understanding the relevance of Darwinian evolutionary theory to law and adjudication.

\section{Jurisprudence and Law}

We turn at last to the applications of evolution in law. The evolutionary metaphor has always loomed over jurisprudential efforts to explicate the nature of the common law; the work of Maine, Holmes, Wigmore, and Corbin drew heavily on the new Darwinian paradigms of their era. However, in the past couple of decades or so the effort to utilize evolutionary theory to illuminate legal and jurisprudential problems has become much bolder and more explicit.17 Contributing to a general tendency in the humanities generally, modern jurists have now begun to extend this scientific theory not only to explain the past of the common law, but also to predict its present dynamic and future direction. 18

The basic task has been divided into three components: a narrative that explains the basic material being described (i.e. case law and legal doctrine), an overall direction or purpose to that narrative, and a mechanism which explains how changes or development are generated. While some accounts focus on only a couple of these components, a few seek to provide an integrated theory that 
claims to tie all three together by way of a simple logic or algorithm. We noted above that analogies to evolution tend to emphasize the 'selection' and not the actual mechanism of change: unsurprising, because that would weaken the analogy considerably. In jurisprudence's efforts to utilize Darwin's insights for explaining the past history, present practice, and future direction of the common law, the same basic intellectual divisions have taken hold. Although these positions vary in their details and nuances, they loosely resemble the general positions in the scientific debate. As currently understood, the main debate in jurisprudence is dominated by the Soapy Sams on the Creationist side and the Bulldogs on the neo-Darwinian side.

In taking this general approach, contemporary jurists participate in the much more expansive project of the humanities which attempts to explain the idea and history of progress through recourse to the prestigious discourse of scientific authority. In these modernist efforts, evolutionary theory has proved a useful and authoritative device: its advocates claim to resolve the complex mysteries of human progress by reference to one simple formula. This is an ambitious project, and if successful will be a truly momentous achievement in the history of jurisprudential thought. However, fortunately or unfortunately, this project cannot be sustained. Despite its obvious academic allure and apparent intellectual pedigree, evolutionary theory has little to offer traditional efforts to understand the development and direction of the common law. If (and this must remain a moot point) Darwin's basic insights have anything to tell lawyers and jurists, it is that evolutionary development is a corrosive idea that does more to undercut the grand explanatory ambitions of mainstream jurisprudence than to ground or achieve them. Darwinians view the world as much more make-do and makeshift than either the legal Creationists or some of the prescriptions of neo-Darwinians allow; adaptations 
are as likely to be bad as good, and as likely to be a by-product of some other adaptive change. As often as not the Darwinian answer to the ubiquitous question of 'what is the broader significance or purpose of something?' is 'nothing'. If this has been a hard lesson for biologists and scientists, it has been a near impossible one for lawyers and jurists to learn and accept.

Ironically, the most potent use of the evolutionary narrative in law has been distinctly non-Darwinian (and not infrequently anti-Darwinian) in thrust and ambition. Evolution has most often been used as a catch-all term for general development and change. Insofar as this usage is entirely casual, those jurists who talk about law evolving do not analogize or seek identification with evolutionary theory. However, not averse to trading off the hard currency of scientific explanation, such theorists connote some aspect of systematic and directed development in their accounts of the common law.19 In its more modest manifestations, such normative scholarship concentrates on one particular area of law and, in a typical boot-strapping manoeuvre, identifies an underlying pattern or organizing principle and suggests that the legal doctrine is developing to give it better and more coherent expression. 20 In its grander form, the claim is made that the whole of the law is moving forward in step with the beat of law's own distinctive drum. It is contended that, although law and adjudication take place within changing social and political conditions, these contexts are simply occasions or opportunities for judges to reflect upon and develop law's essential character; these contexts are not treated as the source or cause of law's changing character. As such, these jurisprudential interventions have a rather inward and miraculous quality to them and posit some hidden designer behind law's development and direction: it is a much resisted, but barely disguised, form of legal Creationism. 'What is law for?' is in many ways an ecclesiastical question.

In contrast to this dominant strain of contemporary jurisprudence, there is a 
variety of scholarship that takes the Darwinian idea of evolution more seriously and sympathetically. This reliance on evolutionary narratives ranges from extended analogies to full-blown homologies. Viewed collectively as a series of complex narratives describing the development of law, morality, social systems, and biological explanations of behaviour, they seek to fuse the prestigious cache of scientific explanation with the normative framework, imputed or asserted, of legal systems.

This is not the place to delineate a typology of arguments deployed in the evolution and law paradigm, but we can suggest some contours. We have already noted that there have been two main phases, a traditional and a modern phase of evolutionary metaphors. Within the modern phase there are several branches exploring different emphases.

The traditional phase connotes gradualist development over time, usually toward some goal or other as seen in hindsight. Examples include works of Corbin, Wigmore or Holmes on common law development. Such analogies are perhaps the most common use of evolution: those that, in the simplest of ways, seek to present development as somehow gradual and inevitable, and at the agency of something with law or legal thinking, that gets revealed by judges in case law and doctrinal development. The most interesting feature is, to our reading, the location of agency in this evolutionary analogy, in a description that must marry change and development with some unitary coherence and unchanging quality, it is perhaps rhetorically necessary to employ descriptive terms that can slip between the passive and the active, or even between descriptive and prescriptive. 21

The modern phase retreats from an explicit directedness to legal development, or perhaps relocates it. These analogies to (and homologies with) evolutionary theory track developments in that theory, and implications for the law and 
evolution paradigm. They especially partake of developments in discourses of 'non-linear models' as applied to biology, or even outside biology. We suggest that there are several schools within this modern phase, including: the 'updated' traditional analogy, which might include the attempt to apply genetic models to legal concepts via 'meme theory'; the broader autopoeitic models, and Habermasian 'learning systems', which are made by explicit analogy to biological theory; 'law-and biology' as promulgated most notably by Margaret Gruter and her intellectual progeny, which emphasizes homological explanations between law and biology; somewhat distinctly, 'complexity theory', 'chaos theory', and other catch-words from non-linear modelling and analysis that attempt not so much to analogize to another discipline as to use the techniques of modelling from that field within or to describe 'legal fields'.22 We suspect that these models, most often arising out of advanced mathematics, are employed as latter-day surrogates to the Darwinian narrative, in the sense that they provide a form of 'contingent closure' by qualitative methods, that is, by methods that describe overall determinist systems but that cannot or do not describe individual outcomes. Finally we feel that 'law-and-economics' must be included in this category. In fact it may be the precursor of 'law-and-biology' in both analogy to and homology with models of dynamic systems, complex models of human behaviour, strong reliance on mass data, its special emphasis on econometric modelling, the operation of a few key principles like efficiency, its historical penetration into new disciplines, and its utter lack of predictive value.

As we have said, we are interested here in teasing out the politics of these positions, not in providing a typology. But an increasing sophistication is discernible in the analogies or indeed the modelling used in the evolutionary paradigm. This includes attempts to vacate these models from any sort of purpose or directedness, or to reframe that characterization in terms of stochastic models 
including terms of art like exogenous and endogenous factors, equilibria, variability, dynamics, and the like. Some go on to claim some 'nature' to law, some merely assert that such analogies are good heuristic devices by which we might understand change and development in law, and test our hypothesis.

Although these approaches differ considerably in emphasis and reach, they rely upon some notion of Darwinian evolution. And for the purposes of this discussion, each theorist tries but fails to avoid falling into the same temptation that ultimately ensnared Huxley: to employ the metaphor or even the method as proof of prescriptive propositions. A more or less random example is Robert Clark's analysis of corporate law. He not only identifies patterns in the development of some areas, but seems compelled to attribute them to law's universal nature: the drift from descriptive analysis to prescriptive proposal is almost seamless.23 Moreover, these legal Darwinians seem unable to keep the notions of evolution and progress separate; they not only see change everywhere, but treat progress as something that is almost inevitable. Indeed, although many of these scholars warn against the pitfalls of a Panglossian mentality, they still manage to put a wonderfully positive and normative gloss on law's development. In so doing, they begin to desert the one commitment that seems to divide the Creationist Soapy Sams from the Darwinian bulldogs: that there is no redemptive or miraculous force that is orchestrating or driving the world forward in a particular direction and to some preassigned destination. Looked at from a traditional Darwinian standpoint, the legal Creationists and the neo-Darwinians may simply be flip-sides of the same coin: they both trade in the same moral currency and barter in the same market-place, albeit with different styles and ambitions. There is no real role for contingency in their models, as there is with evolutionary theory, and much of their efforts are directed at minimizing that particular implication for law. Let us be clear: we are not insisting that there is 
some close analogy between law and biology, especially over the issue of chance. We are observing that the techniques used to persuade, that is, a form of 'contingent closure', are remarkably similar in both camps, notwithstanding their different roots and ultimate claims.

Some will find these claims to be sweeping, and in need of substantiation. Instead of ranging broadly and loosely over the whole of the evolutionary terrain, we will concentrate on the work of two competing scholars whose work we have already introduced. Whereas the work of Ronald Dworkin can fairly be used to typify a Creationist perspective, the writings of Richard Posner can reasonably be drawn upon to exemplify the neo-Darwinian side. Again, it is important to be perfectly clear what we are and what we are not offering. 24 Accordingly, we suggest that, insofar as evolutionary theory has anything to say about development in law (and it is entirely likely that it has very little to say) it tends to support 'critical' rather than mainstream accounts of the common law; law and adjudication are not the grounded, contained, and predictable practices that traditional scholars postulate or imagine. We most certainly do not claim that there is an actual Darwinian dynamic at work in the common law's development and operation: merely that a similar rhetoric is deployed.

\section{When Dick Met Ronnie}

Although the venue has been suitably ubiquitous in this technological age, the occasion for much of the furious and dyspeptic exchanges between Dworkin and Posner has been the antics of President Clinton and the validity of (unsuccessful) efforts to impeach him. Perhaps this is sufficient indication that the stakes are lower than ever. However, like the Oxford debate between Wilberforce and Huxley, the agenda is much broader and more polarized: it pits the established 
legal order, with its metaphysics, against a 'social scientific' paradigm. Beneath the personal invective and collateral point-scoring, there is a very significant dispute over the nature and legitimacy of common law adjudication. Having inherited the mantle of jurisprudential top dog from Herbert Hart, Soapy Sam Dworkin has given eloquent and insistent voice to a naturalist jurisprudence that obliges judges to read law's doctrinal history 'in the best light' with a belief that the law is 'working itself pure'.25 While such noble work and suitable inspiration may elude rank-and-file lawyers, they are not left to their own devices because, aided by jurisprudential 'seers and prophets ... to work out law's ambitions for itself, the purer form of law within and beyond the law we have', their 'god is the adjudicative principle of integrity' .26 In opposition to this frankly theological rendering of the jurisprudential project, Bulldog Posner offers a more pragmatic and scientific challenge that eschews all attempts to relate the worth of grand theory to the practical operation of the adjudicative task: the law is less a theological pilgrimage of legal faith and more a technical craft of bureaucratic policy-making. While there is something to admire in each of these positions, there is much more to reject. Whereas Posner is a typical lawyer who cannot resist turning the powerful descriptive thrust of Darwinian evolution to illegitimate prescriptive effect, Dworkin rejects entirely the critical force of evolutionary theory and reveals that he is more the Creationist than he might otherwise think or wish himself to be.

For Dworkin, therefore, adjudication is a philosophical adventure of the grandest kind, in which formal integrity and abstract coherence are both the tools and the goal of intrepid jurists. While every judge might not have the necessary Herculean wherewithal to master the arcane equipment of philosophical sophistication (which demands that they synthesize all the available historical material, construct a perfectly attuned and all-embracing structure, and apply it 
consistently to detailed legal problems) what is important is that judges should do the best they can by being prepared to embark upon the 'justificatory ascent' that might draw them into a more theoretical argument than they originally anticipated or wanted. Maintaining that reflective height is the guarantor of moral depth, Dworkinian judges are obliged to take a 'theory-drenched' approach, even though they might well disagree over what that theory is and how it applies to the dispute at hand. None the less, he assures judges and jurists that 'the ladder of theoretical ascent is always there, on the cards, even when no one is tempted to take even the first step up it'.27 This potent cocktail contains a volatile brew of ethical optimism and evolutionary inevitability, which has intoxicated many common lawyers and judges. Drinking deep at this particular intellectual well, they are reassured that what they are doing is at the same time politically attractive, ethically defensible, and impersonally driven. It is standard manoeuvre for lawyers and judges to speak of the common law as if it had an existence of its own in which there is the arcane 'invisible hand' of some benign God-like figure at work in its unfolding and growth. For all his earthy wit and political nous, Dworkin's jurisprudence has an entirely otherworldly aspect, in which fundamentalist faith and sectarian devotion play a crucial role. Soapy Sam Wilberforce would have been proud of such a religious call to established arms.

Although this pietistic tendency to gloss the messy, episodic, and undirected workings of the common law as a polished, integrated, and teleological process is endemic to much contemporary jurisprudence, it is by no means universal. Many lawyers and jurists reject such scholarly spiritualism and its claims that law has a miraculous supra-historical life which its faithful juristic adepts can know and understand. The idea that law is an immanent whole that transcends the accumulated sum of its immediate parts, that there is a simple metaphysical 
formula that explains all law, and that legal practice can be rendered philosophically pure is seen to be increasingly untenable in a world in which lawyers and society at large are increasingly diverse in composition, interests, and objectives. These pragmatists insist that their efforts are more grounded, less preposterous, and thoroughly practical in aspiration and execution. Dworkin's plea for 'justificatory ascent' to some abstract remove from which we can catch an echo of the infinitely true and carry it back to society for people's edification and enlightenment is exactly the wrong trip to take. Pragmatists argue that progress is not about becoming more objective and true, about achieving justificatory height in order to attain moral depth, nor about advancing towards some higher more removed and abstract plane on which rationality can hold sway outside of the disabling influence of interests, commitments, fuzziness, history, culture, and ideology: there is no way to escape the politics of human finitude and transmigrate to an infinite realm of pure reason that secures people against the need to make difficult and always contestable choices. In particular, pragmatists maintain that there are no solid and secure footings for law and legal theory that are not themselves part of the very political and situated debate that they are intended to ground and underwrite. In short, there is no escape from the messy and contingent facts of social living.

The most prominent of these pragmatic critics is, of course, Richard Posner. Once a firm believer in the truths of objectivity and integrity himself, he has now put his prodigious energy at the service of a more pragmatic creed and become a Darwinian bulldog who can only be ignored at lawyers' peril. He argues that moral theory not only has little to offer law, but that it is positively dangerous to its actual operation. A Dworkinian pilgrimage takes judges and jurists off into the kind of ideological and indeterminate speculation that is inimical to legitimate lawyering. Drawing explicitly on the writings of 
several neo-Darwinians and in the evolutionary wake of his intellectual hero, Oliver Wendell Holmes Jr, Posner recommends:

an adaptationist conception of morality, in which morality is judgednon-morally, in the way that a hammer might be judged well or poorly adapted to its function of hammering nails-by its contribution to the survival, or other goals, of a society. 28

As such, he maintains that judges can act as evolutionary handmaidens by facilitating rather than steering society's moral development and progress. For Posner, this does not mean that law must be unprincipled or technocratic, only that it is wrong to equate 'moral principle to principle, and morality to normativity'. Instead, he concludes that what is required is that judges develop 'a disposition to ground policy judgments on facts and consequences rather than on conceptualisms and generalities'.29 In other words, judges and lawyers must eschew moral philosophy for social science. In fulfilling this bureaucratic role, Posner recommends that judges and jurists should avail themselves of the economists' empirical tools and work to craft useful solutions to pressing and practical controversies.

Dworkin and Posner showcase the practical implications of their jurisprudential positions in their discussion of the Glucksberg case on the right to physician-assisted suicide.30 For instance, Ronald Dworkin has chastised the Supreme Court for its failure to understand fully the philosophical dimension of adjudication and the ethical responsibilities of judges in interpreting the Constitution. Having joined with other leading liberal philosophers (Thomas Nagel, Robert Nozick, John Rawls, Thomas Scanlon, and Judith Jarvis Thomson) in submitting an amicus brief in support of the respondents, Dworkin was not pleased with the Court's decision. This was not simply because it found resoundingly against his particular views on the best moral and constitutional position on assisted suicide, but because he considered that the Judges had not properly appreciated their sophisticated task as constitutional 
interpreters. Dworkin had little good to say about Rehnquist, Scalia, and Thomas who, in taking an entirely historicist approach and insisting that what has been accepted as politically fundamental is what is legally fundamental, ignored the philosophical and critical element of constitutional adjudication; they reduced it to a crass and conservative enterprise in empirical inquiry. On the other hand, although Souter's judgment was 'reasonable in principle', 31 Dworkin remained unconvinced that the facts were sufficiently in dispute to warrant a hands-off approach by the courts. Nevertheless, with characteristic ingenuity, Dworkin refused to accept that all was lost and, arguing that five of the six Justices who wrote opinions did not reject his ethical stance out-of-hand, hoped that the Court might come to its constitutional senses in the future and validate a constitutional right to die.

Taking the Glucksberg bait, Richard Posner took Dworkin to task for his mistaken views on both how the right-to-die claims should be resolved and what valid constitutional adjudication should encompass. For Posner, Dworkin was barking entirely up the wrong tree in insisting that such disputes require the court to participate in moral theory; this is the problem, not the solution, in understanding the constitutional role of courts in such ethical controversies. In contrast, Posner is adamant that the Supreme Court must deliberately and steadfastly refuse to become bogged down in such philosophical quagmires. His pragmatic commitments advise that courts best fulfil their institutional roles when they 'ground policy judgments on facts and consequences rather than on conceptualisms and generalities'. Accordingly, in Glucksberg the Supreme Court was correct to stay out of the moral debate around the right to die, and to prefer the solid earth of policy analysis to the soggy turf of moral philosophy. There was no obviously shared or objective moral resolution available; democracy was at work and seemed to be proceeding satisfactorily without judicial interference; and the issue demanded very complex rules of implementation which courts are 
ill equipped to draft. In advocating such a consequentialist approach to decisionmaking, Posner does not intend to abandon principled adjudication in favour of ad hoc calculation. He claims that it is simply mistaken to equate 'moral principle to principle, and morality to normativity'. 32 For Posner, Glucksberg therefore is a prime example of the benefits and legitimacy of construing constitutional (and general common law) adjudication as a practical task of institutional instrumentalities rather than as an abstruse exercise in philosophical reflection; whereas the former is something that most judges can and should do, the latter is something that most judges cannot and should not do.

While there is much to appreciate in Posner's pragmatic critique of Dworkinian-style theorizing, this audacious proposal that the empirical tools of economists are morally neutral and ought to be adopted by judges is no less troubling. Indeed, like the earlier Bulldog, Posner manages to subvert Darwinian ideas in the process of championing them; he turns a valid descriptive analysis into an illegitimate prescriptive theory. At the end of the day, by replacing moral philosophy with social science, he is in the same theological game as Dworkin of telling society what it should do if it wants to be a better society. While it is true that judges and jurists would do well to take greater heed of the sociopolitical context in which they work and of the actual consequences of their decisions and suggestions, it is absurd to imagine that this can be done without resort to social values or political commitments. As an empirical matter, it is simply not the case that there is 'a fair degree of value consensus among the judges', such that they can 'seek the best results unhampered by philosophical doubts'.33 Whether in an ethical or scientific guise, theory cannot provide a method that will relieve people from the responsibility and challenge of constantly arguing and rearguing what should and should not be done in particular contexts at particular times. Dworkin is surely right when he argues 
that Posner's claims about the political process are not descriptive or technical but moral, in the sense that they are not only judgements about how best to achieve stipulated goals, but highly controversial claims about the distribution and exercise of government powers and the limits imposed by respect for individual moral rights: '[Posner] calls for the death of moral theory, but, like all of philosophy's would-be undertakers, he only means the triumph of his own theory.'34

While Dworkin is right to chastise Posner for drawing on values, he is mistaken to maintain that this can only be done by buying into the kind of theological theorizing in which Dworkin specializes. There is nothing wrong with suggesting that 'survival of the fittest' or a related standard is a worthy goal, but this cannot be done under cover of evolutionary theory. It simply has to be defended like any moral or political theory. In particular, as a normative initiative, it cannot simply be posited as a fact of nature because this assumes what is the major bone of contention in ethical and political inquiry: what count as 'facts' and 'nature' are contested categories. However, a sound defence does not entail the kind of grand theorizing that Dworkin proposes. For Dworkin there is no choice other than objective truth-'a matter of how things really are'-or subjective opinion-'in our own breasts'. 35 Anything that does not live up to the objective standards of truth is mere conviction, mere convention, mere ideology, etc. This kind of either/or, all-or-nothing thinking misrepresents the possibilities. To be against objective truth does not mean that one is left with only subjective opinion; and to be against only subjective opinion does not imply that one is defending the existence of objective truth. Although the traditional search for objectivity is a lost cause, there are not only subjective opinions and relativized truths. Instead, one truth is not as good as another if one understands by truth nothing more than that it meets the familiar procedures of justification that 
hold sway. It is not about striving to reach a promised land of truth that will make further justification unnecessary. Instead, jurisprudence must become more useful such that success is not vouchsafed by reliance upon a particular epistemic method, but by the usefulness of the results arrived at and their effect upon meeting certain objectives that are taken to be morally or politically significant: moral choice is 'always a matter of compromise between competing goods rather than a choice between the absolutely right and the absolutely wrong $\cdot 36$

Accordingly, instead of reflecting with Dworkin upon universality to justify particular principles (which will turn out anyway as little more than a cover for the theorists' own political or moral agenda) there should be talk along with Posner about the concrete and relative advantages of choosing one over another. However, such talk must be openly moral and political; there is no scientific or factual way to finesse that responsibility and opportunity. Sadly, Posner is pragmatic in the most unpragmatic of ways. Because he accepts much of the contextual situation as given, he restricts himself to tinkering with present arrangements and remains profoundly abstruse and rationalistic in his analysis: 'abstract universality' is ditched, only to be replaced with 'abstract particularity'. There is little appreciation that legal reasoning operates in the real world of historical struggle or of how law does (and does not) change. 37 Giving the idea of social practices a more political than ethical spin brings the operation of power into the centre of debate; consensus (and therefore standards of persuasion and justification) can be treated as imposed as much as chosen. In moving from truth to usefulness, a thoroughly pragmatic jurisprudence does not set out to know things as they really are $a$ la Dworkin or to isolate a scientific criterion of usefulness

a la Posner. In responding to the compelling question of what to do next, both Dworkin and Posner answer with far too much certainty or confidence than 
is good for them or for anyone else: knowledge and usefulness are not stable or secure footings on which the houses of law can be safely constructed. A Darwinian-informed pragmatism is much less modest and much more experimental. And it is to an elaboration of such a perspective that we now turn. In Darwinian terms, law is one more set of tools through which human beings are struggling to cope with the contingent circumstances of their environment and with the realization that these efforts, like the best-laid plans of Robbie Burns' mice and men, often come to nought.

\section{Between A Rock and A Watch}

When Charles Darwin went to Christ's College at Cambridge University in 1827, he stayed in the same rooms as had the former student and fellow, William Paley, fifty years before. Although there is no reason to think that this was more than a matter of curious coincidence, the lives of the two men share a certain synchronicity. In completing his degree, the young Darwin was obliged to study Paley's extensive writings. A theological scholar of some repute, he had been an eloquent proponent of the socalled argument-by-design rejection of evolution. Paley's central contention was that the sheer complexity of biological organisms, especially humans, defied explanation as being the result of chance evolution rather than deliberate design:

In crossing a heath, suppose I pitched my foot against a stone, and were asked how the stone came to be there; I might possibly answer that, for anything I knew to the contrary, it had lain there forever: nor would it perhaps be very easy to show the absurdity of this answer. But suppose I had found a watch upon the ground, and it should be inquired how the watch happened to be in that place; I should hardly think of the answer I had before given, that for anything I knew, the watch might have always 
been there. 38

Darwin was much taken by Paley's work and, in an important sense, spent much of his life demonstrating why Paley's claims were false and that even the most complex of biological creatures or designs required no designing hand or orchestrating intent. However, the most complete refutation of Paley did not come until 1986 when Richard Dawkins took on Paley fairly and squarely. Using Paley's own examples, he showed how it was even more wondrous and aweinspiring that nature's intricate complexity should be the result of gradual and insistent evolution over time than the draughtsmanship of a designing deity. Emphasizing the unplanned, unconscious, and automatic processes of nature, Dawkins concluded that:

natural selection ... has no purpose in mind, ... has no mind and no mind's eye, ... does not plan for the future, ... has no vision, no foresight, no sight at all ... [and,] if it can be said to play the role of watchmaker in nature, it is the blind watchmaker. 39

Darwin was vindicated. And there is no reason to assume that he would have been anything but impressed and approving of Dawkins' efforts. Nevertheless, while Dawkins' work did little more than further confirm and corroborate Darwin's ideas, the extent to which Dawkins and others have been prepared to push that claim has proved controversial. Not content with explaining the evolution of all biological organisms in line with a Darwinian evolutionary dynamic, they have made the audacious claim that the behaviour of such organisms (again, especially that of humans) is entirely explicable in the same terms. Whether scavenging for food or shopping for watches, whether scrambling for sexual supremacy or reflecting on sexual mores, humans and other organisms are striving to adapt to their environment and ensure the survival of the fittest. This is a bold and unsettling claim that has considerable relevance to the debate about the development and operation of the common law. Of course, 
the power of a good idea is to be found in its limits as well as its depth. In this, Darwinian evolution is no exception. What tends to divide Darwinians is less the precise operation of an evolutionary dynamic, although there are competing views over this issue, but the general scope of its applicability.

Probably the main bone of contention between the Darwinians and ultraDarwinians is the application of Darwin's ideas to human behaviour. 40 There is general agreement that, because humans are a species, their creation and development are readily explicable by the logic of Darwinian evolution. This does not mean

that the existence of humans was inevitable or planned and nor does it mean that their continued existence is guaranteed. Like dinosaurs and dodos, humans are vulnerable to the extreme deprivations of their natural environment. This may be so, and as legal writers we are ill-equipped to evaluate the notion. But we can suggest some troubling points for at least the traditional understanding of 'evolution'. Unlike all other organisms (to date), humans have a greater and more sophisticated capacity for conscious planning and for impacting the environment in which they live; they manage to affect and shape their environment as they are affected and shaped by it. Consequently, human development is not entirely reactive or adaptive; people are able to exert a powerful influence on some of the factors-notably, those that are emphasized in 'selection' or a notion of a naturally-occurring 'environment.'41 This means that any attempt to reduce the study of human activity to familiarity with the same evolutionary dynamic as works for fish and fowl may be ultimately unconvincing: it may be futile to ask 'are humans evolving?' in the traditional sense.

A key question, therefore, for Darwinian adherents is how to account for those human behaviours that are the result of conscious planning and intellectual design-can they be brought within the explanatory provenance of a modified 
Darwinian dynamic or are they outside its descriptive ambit and, therefore, a challenge to its whole scientific status? One of those human processes is law which, at bottom, is a collective human endeavour to cope with and control human affairs, and perhaps even the world around us; it is an artefact, like morality and psychology, that seeks to check as much as adapt to the environmental forces which comprise its nurturing context. Accordingly, at the heart of the intersection between evolution and law are the problematic claims for the nature of human progress and the progress of human nature.

Biologists might safely limit their project to describing how evolution works: but accounts of law cannot take the narrower scope, for their subject matter is ethics, or politics if you will. To biology, it hardly seems necessary to add the human elements of will, design and purpose (which some use evolution to support) which are very likely not knowable entirely through experiment or 'long catalogues of facts'. Since the first wave of social Darwinism, this unknowability has been challenged or imputed in different ways by the claims of sociobiology, law-and-biology, etc. In terms of the actual cause of change in individuals and species, the prevailing doctrine in evolutionary biology is clearly committed to the view that random change or chance errors in replication at the genetic level actually cause variation in individuals. This concept of change is at odds with most uses of the evolutionary metaphor in law and works quite against the traditional directed idea of an evolutionary narrative. As such, the exact correspondence of law and biology is not supportable. Law does not have 'species' nor does change occur independent of human endeavour, it is not directly subject to the theory of evolution or its explanatory power, no matter at what level evolution operates. The only plausible comparison between law and biology is in terms of relative analogy. Because humans are perhaps the only beings that have been able to transform 
their own environment so radically, it is not easy to claim that such behaviour is 'selected' in the classical narrative sense so that there is a sense of directed change; it is better seen as part of a more complex interplay between humanity and its environment. If law is a social construct and human behaviour is transformative of its context, there is a very different dynamic at work from that of the traditional evolutionary metaphor. Moreover, as well as its troublesome naturalistic (i.e., explanatory power converts to predictive authority) and deterministic tendencies (i.e., genetic or behavioural traits are predetermined), the evolutionary narrative also works equally badly the other way by reducing law's ethical dimension to bare description; this is simply another way of attempting to further the illusion that law is separate from politics and to deny the force of the critical claim that 'law is politics'.

Saying this much may merely be accusing proponents of evolution in law of making selective analogies or choosing poor metaphors, and to suggest how such constructs are ultimately unpersuasive. But a sense of the broader challenges-the accusations of vulgar reductionism, or thinly disguised theism, and even the import of a measure of indeterminacy, as we have suggested above, have all led to attempts to improve the model. The most theoretically interesting is probably the latter, which has led, we suggest, to the analogies to various forms of qualitative reasoning in other areas (including biology) that themselves try to cope with levels of indeterminacy within deterministic systems. It is easy to see the attractions for accounts of common law development.

Some efforts to overcome some of these debilitating problems have concentrated on developing a parallel and complementary process to Darwinian accounts of biological change that can explain cultural development. For instance, Jack Balkin has sought to provide an account of how shared understandings in law grow and spread from one generation to another. Drawing on the work of 
Richard Dawkins and Daniel Dennett, he picks up on an understanding of natural selection as a neutral, algorithmic process, applicable to an extremely wide range of phenomena and capable of achieving immense feats by slow accumulation over large extents of time and space. Balkin contends that, while basic physiological information is contained in genes and is passed down through reproduction to new generations, there are also 'memes' which play a similar function to genes in facilitating the transmission of abstract ideas through cultural exchange over time. He argues that all mental and cultural life, including law, is adequately explainable by a mechanical Darwinian process of natural selection in which genes and memes struggle for survival. Seeking to fuse concepts of function in biology and meaning in philosophy, the theory utilizes adaptionism as a fertile source of both biological and social explanations. Rejecting the notion of any Panglossian tendency at work, Balkin asserts this evolutionary process is less Darwinian than Lamarckian in that adaptation and variation occur in direct response to the environment rather than as part of a contest between random variations to fit better the environment. 42 In short, he offers a less assertive form of autopoietic development using mimetic units. However, in attempting to provide a scientific basis for cultural evolution, from a political-ethical perspective, Balkin manages to offer a process that is clinical and sterile in its political content; his theory of ideology is all so neutral and comforting in presenting the interaction between people and their social environment as relatively benign and harmless. Moreover, the alleged analytical strength of this kind of ultraDarwinian theorizing runs out at the very point at which it might be thought to be most needed; the Panglossian tendency cannot be so easily cabined or contained.

Like other homological approaches, such an approach rests (consciously or unconsciously) on the applicability of forms of measurement of problems within the home fields (biology, sociology, even epidemiology) within the 'legal fields'. 
There are a couple of initial objections to these explanations of change and development when applied to law. The first is that, like the traditional evolutionary narrative, the method may risk serious misapplication outside the 'home' discipline or problem. The applications of 'chaos theory' or 'catastrophe theory' are a couple of examples with filiations in biology. Aside from their nomenclatural problems (they are really misnomers in the common sense of those words), these two theories are models that select a fact or two out of a large tangle of them, and suggest patterns of subordinate facts, much in the way evolution does. They are not predictive or determinative, merely suggestive of an explanation, a mathematical guess at a pattern to look for. They provide, in use, a form of very formal contingent closure to a proposition, but (we contend) there is not an overriding theoretical or evidential reason to prefer this form of proof over any other. Additionally, the suite of propositions to which they may be applied is probably limited, and they do not appear (on our cursory reading) to be generalizable to fields such as ethics or even something called 'law and biology', notwithstanding attempts to characterize, say, prison mutinies as 'dissipative systems' obeying the contours of Rene Thom's catastrophe theory, or applications of Lorenz's 'sensitivity to initial conditions' to literary theory. Our main interest is the attraction these forms of qualitative reasoning-those coping with some level of indeterminacy-have for legal theorists.

At any rate, they may have another related but more serious limitation: they are descriptive models, and like much economic analysis, they have very little to say, strictly speaking, about how law, an ethical inquiry, will or ought to develop. If we take law seriously as an ethical enterprise, we do ourselves a disservice to then re-invent (reveal?) patterns of human nature that law must obey. Yet these models are employed as a sort of rhetorical proof, resplendent with the nomenclature of higher mathematics, that suggest this very step, as we 
have argued at length above. The use of these analogies and metaphors is not limited use, and they contain understandably attractive qualities to those writing about common law problems.43 But they are ultimately unpersuasive of the 'evolution' of common law.

However, to resist the ambitious claims of these ultra-Darwinian theorists does not mean that a Darwinian explanation has no role to play in explaining and understanding legal development. To challenge cultural determinism is not to align oneself with the genetic determinists and to reject socio-biology is not to subscribe to a Creationist creed. Too often, what begin as correctives to the excesses of existing theories become full-blown and equally excessive alternative theories. Dworkin is surely right when he insists that 'moral reflection, through various layers of justificatory ascent including the philosophical, is as much a part of human nature as anything else'.44 Yet, to deny the universalistic and deterministic claims of a pseudo-scientific approach to law and adjudication is not equivalent to taking the position that philosophy and justificatory ascent are equally determinative or comprehensive in their description of law. Even if judges did all engage in such heady flights, there is no reason to think that the resulting abstraction would be congruent or coherent. Indeed, the assertion that there is some presence or generation of Purpose(s) from within the legal system itself is very problematic. Even assuming that law can be described as something organically distinct from other practices of political human behaviour, the phenomena described (i.e., laws, doctrines, cases, etc.) are actually characterized as passive or automated entities. However, as soon as the analysis shifts to self-movement, learning, and self-reflexivity, the entity has itself assumed to have some form of active life. In rhetorical terms, there has been a slippage from scene to agent and from description to purpose in which the system itself is imbued with a definite normative content. From that point on, it is all too quickly and easily presumed that uniform behaviour gets treated as evidence of a unity or harmony of 
interests. This becomes an invisible hand in classical economics, is generalized and made more systematic as class interests in Marxian economics, and manifests as normative coherence in liberal jurisprudence. (We note here that in this sense Smith was the original author of the 'communistic fiction').

But of course, ascribing a 'harmony of interests' does not do the work of explaining transformation in law without importing an operating principle of agency from outside. In fact, these systemic narratives of evolution attempt to have it both ways in their insistence that agency and context combine to produce change: the organism of law becomes depicted as something more than a passive body of conjoined phenomena, but not sufficiently active or political to be an integrated part of the larger political world.

The whole idea of law 'working itself pure' is anathema to any kind of evolutionary account of law. Even under the most modest and non-systemic account, evolution is most certainly not a purifying process in which deviant forms are eliminated so that a species' true being can assert itself. Also, such a jurisprudential account runs up against the problem that, if law became perfectly adapted to its social and philosophical role, any change in the environment would immediately ensure that law was unsuited and unresponsive to challenges that occurred. As such, if the idea of law 'working itself pure' is to have any validity or bite, it must rest on a particular theory of social development-that society will also reach a point of political equilibrium in which social tensions are in both philosophical and practical harmony-that is both fantastical and reactionary. Such assumptions place Legal Creationists in the dubious camp of end-of-history prognosticators like Francis Fukuyama who maintain that 'there is a fundamental process at work that dictates a common evolutionary patent for all human societies-in short, something like a universal History of mankind in the direction of liberal democracy.'45 Hegel never had such strange bedfellows: 
but if that is a serious proposition, then we might legitimately wonder how it is to be proved in so open a system. The contingent closure of the evolutionary narrative provides a handy argument. Ironically, in rejecting the merit of a Darwinian approach to legal and political development, these liberal democrats rely on exactly the same kind of evolutionary trope in explaining and justifying the working-pure character of law and social institutions. As such, the denial of Darwinian insights' relevance to legal and social development is both contradictory and confusing.

Accordingly, the challenge for those who insist upon the pertinence of Darwinian evolutionary insights for law is to include and explain the role that such 'moral reflection' plays in human behaviour and social development generally. What people do is affected by what people think they are doing. Unlike with other creatures in the rest of the natural world, humans are a species that has selfconsciousness and, therefore, can reflect upon the nature of its own doing. In this, lawyers are no different from other social actors. To different extents and with varying awareness, what lawyers do is affected by what it is that they think that they are doing and what it is that they think that they ought to be doing. Without some incorporation of that crucial element in any explanatory equation, the effort to understand judicial practice and legal development will be found wanting. Where we might say Darwinism is about variation and contingency, a Dworkinian jurisprudence is about convergence and purification. Insofar as the constraints on evolution are historical and environmental, behaviours only change to the extent that the local context allows or requires. As one biologist neatly captures the operation of the evolutionary dynamic, 'the archaic features of life merely reveal its tortuous history, like the archaic features of human language or common law.'46 Any effort to obscure or sidestep that history will fail to capture an important dynamic in law's development. Rather than being on a 
pre-assigned route to some exalted or transcendental state, the common law is simply a continuing work-inprogress that is always moving, but never arriving and that is always on the road to somewhere, but never getting anywhere in particular. Perhaps what really demands explanation in the common law is not the phenomenon of change, but the existence of stability.

\section{A Modest Proposal}

It has lately become the fashion (again) to marry a criticism with a proposal, no matter what sort of progeny such a marriage may produce. Wishing to uphold critical vows, and live by them, we offer some tentative thoughts about how we might frame a discussion of change and development in the common law, with an emphasis on location of change and development, and the very political and contingent character of law.

The illusion of total command is maintained by a willingness to accept that the environment will need to be respected. While it is true that law might 'evolve in the direction of greater fit with its environment',47 there will always be a productive tension between the law's notion of fit and the changing social, political, and cultural make-up of that environment. In short, law will always be a relatively open-ended and stylized form of politics in which 'anything might go'. That 'anything' rarely does go is an indicator not of natural qualities to law, but of persistently constructed constraints that need examining for relevance and validity. This is arguably what law does, albeit imperfectly.

Even if law is understood as an adaptive process through which people mediate the always contingent, usually contested, and often contradictory demands of human living, there is no reason to think that it will have any great success. Indeed, the very criteria for assessing success will be as contingent and 
contested as the process itself. Whereas ultra-Darwinians are intent upon demonstrating that almost all human behaviour can be explained as having its roots and explanation in the biological adaptation to environmental conditions, Gouldians insist that much human behaviour is maladapted and is likely to be the unanticipated result of something which did have an adaptive function. In short, the world is too contingent and complex to submit to such reductionist accounts. Often, the answer to the ubiquitous question of 'what is the purpose of $\mathrm{X}$ ?' is 'nothing'. $\mathrm{X}$ developed as a by-product of some other adaptive change and, as such, might or might not turn out to be more useful and lasting than the initial adaptive change itself. Similar to the biological world, the legal world has its share of maladaptation in that the good and the bad, the adaptive and the maladaptive, can be packaged in a single unit (the Good-Bad) that must be taken as a whole. Unlike the wishful thinking of many jurists, law may be closer to the scenario of jerry-built morphology, second-best physiology, and makeshift behaviour: 'the useless, the odd, the peculiar, the incongruous' are the 'signs of history' that are as much part of the evolutionary narrative as any other and, if excluded or marginalized, will entirely invalidate any account.48 In an open system, it is probably impossible to bring all instances of the proof within the proposition. It can only appear so.

As such, one consequence of this ought to be some recognition that there is no one and even no optimal strategy for dealing with the biological or legal world that can guarantee success. Also, in some configurations, the adaptionist argument is so banal that it gets no further than the Creationist. Because everything that does happen must happen, so to speak, it has no critical edge or interesting force, and instead lulls us into a deeper dogmatic slumber. In our appropriated Darwinian vocabulary, adaptation is a process of becoming rather than a state of final optimality, because any reliance on the notion of perfect 
optimality would undercut the constant dynamism at work in nature and pave the way for the resurgence of Creationist thinking.

Knowledge of the 'how' of evolution does not mean that we are any more likely to know or calculate what will happen next by way of predicting future development or direction. Rather than grope vainly towards a theory of everything for everywhere at every time, it is better to think of trying to draw more pragmatic lessons from legal traditions, development, and change. Some of the law and evolution paradigm does just this, subject to the criticisms we have laid out here. The question 'what do we want law to be, and how has that been achieved traditionally, in any given circumstance?' is a better focus than 'What is law's essential nature?' Of course, there can be workable theories of development and change, even some level of prediction at a very local level and in specific contexts, but the 'larger questions' might never be resolvable in any useful or persuasive manner: the contingencies of social life, and our very limited understanding of them, ensure that confidence or certainty in final solutions will remain elusive. This is no bad thing. As Popper delightfully noted, 'there can be no explanation which is not in need of a further explanation' .49 Or, to express that in a way more salient to this essay, legal theory is never an answer that can speak for itself: it all depends on the political context, which of course always speaks out of both sides of its mouth and in a garbled accent.

In terms of law, therefore, it is important to grasp that an evolutionary perspective is not about generating an agenda for change or a justification for law's particular development. Instead, it is about developing an attitude or approach to law that recommends, among other things, cultivating a healthy scepticism about formulaic recipes for legal success, about simplistic notions of legal progress, about the predictive power of so-called rational planning, about the temptation of reductionist explanations, and about the sense that we are or 
can ever be entirely on top of things, even if we are in the Hart Chair in Oxford. Lawyers need to nurture situation-sense and practical savvy as much as philosophical sophistication and abstract theorizing. Evolution talks in terms of natural selection as being about solving problems, but it must not be forgotten that it has nothing to tell us about the problems that will require solutions: this is a crucial insight for law as well as certain stripes of evolutionists. In a jurisprudential manner of speaking, common law judges offer up what they believe to be the best answer to a problem out of a series of possible good answers. However, in law as in biology, it remains the case that 'even if you can build a bottle from which the desired genie emerges, you can't reduce the genie to the bottle once it's out'.50 Nor, it can be added, is it possible to understand what the genie is capable of doing without appreciating the origins of the genie, its relation to the bottle, and the forces that brought it into play in the first place.

As with much else, the relation between biology and human behaviour, including theories about their relationship, is likely to be variable, complex, and indirect. In an important sense, this tension in law constitutes one more corner of the action in the familiar battle between 'nature' and 'nurture'. It is hard to believe that it is an either/or choice. It is perhaps safer to suggest that it is a mix of both which occurs in a contingent and intricate way.51 Accordingly, although it might be tempting to dismiss all law-andbiology positions as vulgarly reductionist or crass essentialism, it would be mistaken. While law's development cannot be reduced to a simple evolutionary dynamic, this does not mean that there are no evolutionary forces at work. The role of evolutionary factors will be appropriately contingent and changeable. Viewed in this way, both Dworkin and Posner can be understood as being right and wrong. They are right because their accounts do offer robust insights into how the law is viewed, created, and 
changed; they each have something to tell us about the dynamics of legal change and judicial reasoning. But they are wrong in that they treat those helpful insights as universal sagacity about the nature of law and adjudication. The kind of non-foundationalist critique that we have offered is only partially concerned with questioning the explanatory validity of law-and-economics and law-andbiology accounts, but is certainly troubled by normative or totalizing claims. These accounts still may be invalid, or at least not useful models for legal behaviour, but this is not to deny their attempts to understand it in a systematic way. To the extent that these systems provide explanations of the development of law and manage to avoid creating false notions of autonomy or positing internal values to legal systems, they are useful projects that can indeed tell us something about legal development and change. However, when so understood, they cease to be the kind of foundationalist theories which both Dworkin and Posner offer, and instead they become non-foundationalist projects.

\section{Conclusion}

In this essay we have not sought to assert the claim that evolution is applicable to legal development. To be sure, law is a self-reflective process of rational thinking, but it is far from reducible to an activity governed by a strict philosophical discipline that is entirely internal to legal practice. All the talk about grand purposes or guiding minds is pitched at such a high level of generality that what they might or might not recommend in any particular situation is almost impossible to predict. Or, to turn that around, the solution to any particular problem can be interpreted in accordance with a variety of very different, often competing, and occasionally contradictory ideals, each of which can claim a plausible threshold purchase on the extant legal materials. 
Consequently, while law is undeniably a teleological enterprise in that judges act with a purpose, the system as a whole cannot be said to have a directing mind such that it moves forward in one direction as if pulled along toward a given goal. Even the characterization of a 'harmony of interests' is problematic. Indeed, after Darwin it has become possible to admit that 'humans have to dream up the point of human life and cannot appeal to a non-human standard to determine whether they have chosen wisely ... [and that] the meaning of one human life may have little to do with the meaning of any other human life, while being none the worse for that'.52 In law there are many theoretical possibilities, but the actual decision made is as much about external circumstances as anything else: principles prosper or perish not only by dint of their intellectual merit, however that might be measured, or by ethical sophistication, but also by their capacity to adapt to material conditions. Holmes' warning has been ignored, especially by those evolutionary jurists who claim to follow in his intellectual footsteps: 'we have evolution in this sphere of conscious thought and action no less than in lower organic stages, but an evolution which must be studied in its own field'. ${ }^{53}$

We have presented a brief metaphor for change and development in law, but this is just an example to suggest other emphases in critical thinking. Ours is not a claim that the common law is one thing or another. In particular, we do not contend that the common law does or does not function and develop in line with an evolutionary logic. The most that can be said is that, insofar as evolutionary theory has anything to say about law (and it is entirely likely that it has very little to say) it tends to support 'critical' rather than mainstream accounts of the common law. By that, we mean that treating law as if it were susceptible to an evolutionary explanation does not advance the jurisprudential cause of those who insist on claiming a certain autonomy, simplicity, systemization, and directionality to law's 
development. Far from it: if anything, viewing law through the lens of evolutionary theory offers some support to the central critical claims that 'law is politics' and that the nature of that connection is unpredictable and contingent: law's operation and practice simply will not conform to a reductionist and predictive algorithm. The salutary lesson of the evolution debate is that the best story is the one that weaves together lots of different threads in a quilt which is as complex and as complementary as circumstances allow; there is no one set of simple rules that can capture or explain the complexity and contingency of life. Indeed, in a lesson that is singularly pertinent to law, it is stability or stasis that is to be explained, understood, and perhaps even justified.

Abandoning the solace of divine procreation ought not to be a cause for despair or resignation. Instead, it might galvanize jurists into the realization that 'moral inquiry is our struggle, not nature's display'.54 And, insofar as law is one of the main institutional sites and practices through which contemporary society takes part in that struggle, lawyers and judges might accept their participation as genuine surrogates for the democratic citizenry, not as false conduits for a philosophical truth. Evolution is a responsibility, not a necessity. Neither the Soapy Sams nor the Bulldogs of the jurisprudential world exhaust the possibilities for understanding law's development. We need both of them: one as a hopeful reminder that we must strive to rise above the limitations of our own predicament and interests, and the other as a sober caution that we are as much beasts as gods. And much else besides. 
1 See Dworkin, 'Pragmatism: Rights Answers and True Banality', in M. Brint and W. Weaver (eds.), Pragmatism in Law and Society (1991) 359 at 360;

R. Posner, The Problematics Of Moral And Legal Theory (1999) 240; Dworkin, Posner's Charges: What I Actually Said, <http://www.nyu.edu/gsas/dept/philo/ faculty/dworkin/papers/posner>; and Posner, 'Dworkin, Polemics, and The Clinton Impeachment Controversy' (2000) 94 NW. ULRev. 1023 at 1046.

2 'Review', Q. Rev. 108 (Summer 1860) 225 at 231, 225-6. There is no contemporaneous or verbatim record of the encounter and what is known had to be pieced together from Huxley, Hooker, and Darwin's recollections as well as other journalistic anecdotes. See R. Clark, The Survival Of Charles Darwin: A Biography Of A Man And An Idea (1984) 137-47; M. White and J. Gribbin, Darwin: A Life In Science (1995) 219-25. We have presented this famous exchange in its usual formulation, but it is useful to note that parts are considered apocryphal, and that in fact the exchange may have been more substantive and somewhat less frothy than its subsequent rendering has suggested. See, for example, the special 'Darwin Anniversary Issue', Victorian Studies 3(1) (1959) 3; J. R. Lucas, 'Wilberforce and Huxley: A Legendary Encounter' (1979) 22(2) Historical Journal 313. In typical fashion, Gilbert (of Sullivan fame) offered a neat riposte; 'Darwinian man though well behaved/At best is only a monkey shaved': W. S. Gilbert, Princess Ida.

3 Lucas makes the good observation that Soapy Sam's challenges to Huxley, as Darwin's representative, are actually good challenges to the gaps in the Darwinian hypothesis (as it then was). These gaps were closed 100 years later in the New Synthesis, but at the time, Sam had a good grasp of the problems. Lucas reports that Darwin took Sam's criticisms seriously, if defeatable. See $\mathrm{n}$. 2 above.

4 R. Levins and R. Lewontin, The Dialectical Biologist (1985) 9. Interestingly, even the Pope has felt moved to acknowledge the force of Darwinian ideas: "Today. . . fresh knowledge has led to the recognition that evolution is more than a hypothesis. It is indeed remarkable that this theory has been progressively accepted by researchers ... The convergence, neither sought nor fabricated, of the results of work that were conducted independently, is in itself a significant argument in favour of this theory.' Pope John Paul II, 'Address to The Pontifical Academy of Sciences', 1996, as quoted in D. Burnie, Get A Grip On Evolution (1999) 185.

5 B. Latour and S. Woolgar, Laboratory Life: The Social Construction Of Scientific Facts (1979) 237. See also T. Kuhn, The Structure Of Scientific Revolu- tions, 3rd edn. (1996). This is not to suggest that science and politics are the same, only that they are not as separable or independent as is often thought.

6 Darwin's work is sometimes cited as an example of early qualitative reasoning (as the term is understood in mathematics), a line of inquiry that becomes important in discourse analysis and the development of a scientific 'proof'. See I. Ekeland, 'Mathematics and the Unexpected', Chicago: University of Chicago Press (1988). Pursuing this aspect in a discourse analysis, see also S. Archer, 'Missing Links: The Rhetoric of Evolution and Legal Theory' (unpublished: archived with author, 2000) on rhetorical aspects of qualitative reasoning in law and social sciences.

7 S. Jones, Darwin's Ghost: The Origin Of Species Updated (1999) 329.

8 Lamarck and Darwin had access to much similar data, and in a sense merely arranged it according to different hypotheses. Indeed, in our reading, Lamarck's has the advantage of being more intuitive than Darwin's, more causally direct, although 'accounts' for less data, that is, less of the fossil record.

9 Charles Darwin, The Autobiogra phy of Charles Darwin 1809-82 (N. Barlow, ed., 1958). Darwin did not use the word 'evolution' until the 5th edition of The Origin of Species in 1869.

IO It was left to later biologists, especially through the posthumously published work of the Bohemian monk Gregor Mendel, to explain the precise genetic process by which variation and mutation occurred. Darwin could only report that 'our

ignorance of the laws of variation is profound'. See Charles Darwin, On The Origin Of Species By Natural Selection (1859).

11 See A. Somit and S. Peterson, The Dynamics Of Evolution (1992); S. J. Gould, Ontogeny And Phylogeny (1977). For an accessible introduction to this technical debate, see S. J. Gould, Wonderful Life: The Burgess Shale And The Nature of History (1989). See also e.g. R. Dawkins, The Extended Phenotype: The Long Reach Of The Gene (1999); R. Lewontin, S. Rose, and L. Kamin, Not In Our Genes: Biology, Ideology And Human Nature (1984).

12 One of the most sophisticated defenders of the Creationist argument is Phillip Johnson, who is incidentally a law professor: see P. Johnson, Darwin On Trial (1991). For a critical account of the history of the Creationist stance see R. T. Pennock, Tower Of Babel: The Evidence Against The New Creationism (1999); R. L. Numbers, The Creationists: The Evolution Of Scientific Creationism (1992).

13 See T. H. Huxley, The Struggle For Existence In Human Society (1887). For an engaging biography of this Victorian renaissance figure see A. Desmond, Huxley: From Devil's Disciple To Evolution's High Priest (1997). However, the use of Darwin for political purposes was not always 
reactionary. For example, the 19th-century Russian anarchist aristocrat Peter Kropotkin argued that evolution results more in co- operation than it does in harsh competition: see P. Kropotkin, Mutual Aid (1902).

14 The Origin of Species, n. 10 above. In the 1872 edition Darwin added a rider to his original thesis: 'I placed at the most conspicuous position-namely at the close of the introduction-the following words: "I am convinced that natural selec- tion has been the main but not the exclusive means of modification". This has been to no avail. Great is the steady power of misrepresentation.'

15 See R. Dawkins, The Selfish Gene (1989); D. Dennett, Darwin's Dangerous Idea: Evolution And The Meanings Of Life (1995).

16 A. Brown, The Darwin Years: The Scientific Battle For The Soul Of Man

(1999) 154

17 For a brief history of this historical division and other suggestions, see Hovenkamp, 'Evolutionary Models in Jurisprudence' (1985) 64 Texas L. Rev. 645; Elliot, 'The Evolutionary Tradition in Jurisprudence' (1985) 85 Columbia L. Rev. 38; A. Watson, The Evolution Of Law (1985).

18 It is interesting that this 'second wave' of evolutionary analogies coincides with developments in qualitative reasoning as applied in biology (populations stud- ies and genetics), and in the social sciences.

19 See Stern, 'The Genesis and Evolution of European-American Constitutional- ism: Some Comments on Fundamental Aspects' (1985) 18 Comp. and Int. LJ SA 187; Mead, 'Evolution of the "Species of Tort Liability" Created by 42 USC $\S 1983$ : Can Constitutional Tort Be Saved From Extinction?' (1986) 55 Fordham L Rev. 1; and Sward, 'Values, Ideology, and the Evolution of the Adversary System' (1989) 64 Indiana LJ 301. A particular favourite is Dhooge, 'From Scopes to Edwards: The 60 Year Evolution of Creationism in the Public School Classroom' (1988) 22 U. Rich. L. Rev. 187.

20 This 'identification of patterns' may itself be a suasive element in these argu- ments, and that may be part of the reason this analogy to evolution is so enticing despite its problems. Elsewhere, Archer has argued that this is a form of 'contin- gent closure' akin to qualitative reasoning that operates as the proof of the propo- sition, for example, that the 'common law works itself pure'. See Archer, n. 6 above.

21 See Ward, 'The Movement from Vigorous to Malicious Defence as an Exam- ple of the Evolution of Legal Principles' (1986) 47 Montana Law Review 101; Clark, 'The Interdisciplinary Study of Legal Evolution' (1981) 90 Yale L] 1238; Sinclair, 'The Use of Evolutionary Theory in Law' (1987) 64 U. Detroit L. Rev. 451; Rodgers, 'Where Environmental Law and Biology Meet: Of Panda's Thumbs, Statutory Sleepers, and Effective Law' (1993) 65 U. Colorado L. Rev. 25.

22 See Fried, 'Evolution of Legal Concepts: The Mimetic Perspective' (1999) 39

Jurimetrics 291; Ruhl, 'Fitness of Law: Using Complexity Theory to Describe Evolution of Law and Society and Its Practical Meaning for Democracy' (1996) 49 Vand L. Rev. 1407; J. Balkin, Cultural Software: A Theory of Ideology (1998); Jacobson, 'Autopoietic Law: The New Science of Niklas Luhmann' (1989) 87 Mich L. Rev. 1647; May, 'Science, Politics and the Evolution of Law and Neoclassical Economics' (1997) 15 Law and History Review 333; Hackney, 'Law and Neoclas- sical Economics: Science, Politics and the Reconfiguration of American Tort Law Theory' (1997) 15 Law and History Rev. 275; Roe, 'Chaos and Evolution in Law and Economics' (1996) 109 Harv. L. Rev. 641; Elliott, 'Law and Biology: the New Synthesis?' (1997) 41 St Louis UL] 595; Jones, 'Law and Evolutionary Biology: Obstacles and Opportunities' (1993) 10 ]. Contemporary Health and Policy 265; and idem, 'Law, Emotions, and Behavioural Biology' (1999) 39 Jurimetrics 283.

23 See Clark, n. 2 above. For a decisive critique, see Kennedy, 'Cost-Reduction Theory as Legitimation' (1981) 90 Yale L] 1275.

24 Although he reaches some formalistic conclusions about law, Lawrence Tribe's cautions are worth noting on the benefits and pitfalls of utilizing science to understand law. See Tribe, 'The Curvature of Constitutional Space: What Lawyers Can Learn From Modern Physics' (1989) 103 Harv. L. Rev. 1; idem, 'Seven Deadly Sins of Straining the Constitution Through a Pseudo-Scientific Sieve' (1984) 36 Hastings LJ 155.

25 See R. Dworkin, Law's Empire (1996) 256 and 407.

26 Ibid., 407, 400, and 220.

27 Dworkin, 'In Praise of Theory' (1997) 29 Ariz. St. LJ 353 at 359.

28 Posner, 'The Problematics of Moral and Legal Theory' (1998) 111 Harv. L. Rev. 1637 at 1641. Posner is partial to the work of Dawkins and other ultra- Darwinians. Holmes was influenced by biological studies and compared the trans- formations of legal doctrine to organisms' adaption to environmental conditions. See 'The Path of the Law' (1897) 10 Harv. L. Rev. 457; and 'Law in Science and Science in Law' (1899) 12 Harv. L. Rev. 48

29 R. Posner, The Problematics Of Moral and Legal Theory (1999) 133 and

227. See also C. Sunstein, One Case At A Time: Judicial Minimalism On The Supreme Court (1999); and Elliott, n. 22 above.

30 See Washington v Glucksberg, 521 US 702 (1997).

31 See Dworkin, 'Assisted Suicide: What the Court Really Said', NY Rev. of Books, 25 September 1997. The main moral claims of that brief were, first, that competent dying individuals have, in principle, a right to decide for themselves how to die, and secondly, that even if recognizing that right would to some degree increase the risk that other patients would be pressured into choosing death 
against their will, that increased risk does not justify refusing to recognize the right at all. See Dworkin, 'The Philosophers' Brief', NY Rev. of Books, 27 March 1997, 41-7; and Dworkin et al., 'The Fifth Annual Fritz B. Burns Lecture: Euthanasia: Morality, and the Law' (1997) 30 Loy. LA L. Rev. 1465. According to Dworkin, none of the Justices ducked both of these claims; three of them decided against his position on the first and five on the second. See also Dworkin, 'Reply', Ariz. St. LJ 29 (1997) 431; and idem, 'Assisted Suicide and Euthanasia: An Exchange Between Yale Kamisar and Ronald Dworkin', NY Rev. of Books, 6 November 1997.

32 Posner, n. 29 above, 227 and 133. Souter has also been taken to task for his inability to justify the exclusion of economic liberties from substantive due process doctrine: see Meese, 'Will, Judgment, and Economic Liberty: Mr Justice Souter and The Mistranslation of the Due Process Clause' (1999) 41 Wm. \& M.L. Rev. 3. For other critiques, see 'Symposium on Physician-Assisted Suicide' (1999) 109 Ethics 497; Jennings, 'The Liberal Neutrality of Living and Dying: Bioethics, Constitu- tional Law, and Political Theory in The American Right-to-Die Debate' (1999) 16

]. Contemp. Health L. \& Pol'y 97.

33 Posner, n. 29 above, 262.

34 Dworkin, 'Darwin's New Bulldog' (1998) 111 Harv. L. Rev. 1718 at 1738-9.

35 Dworkin, 'Objectivity and Truth: You'd Better Believe It' (1996) 25 Phil. \& Public Affs. 87 at 92. See also D. Farber and S. Sherry, Beyond All Reason: The Radical Assault On Truth In American Law (1997) 7, 22, 73, 119, 133.

36 R. Rorty, Philosophy And Social Hope (1999) xxxii, xxix.

37 See D. Kennedy, A Critique Of Adjudication Fin De Siecle (1998); Hutchin- son, 'Casaubon's Ghosts: The Haunting of Legal Scholarship' (2001) 21 Legal Studies 65.

38 W. Paley, Natural Theology (1802; rep. 1970).

39 R. Dawkins, The Blind Watchmaker (1986) 5. But see also 'irreducible complexity' above, which offers a critique of evolution along much the same lines.

40 See above.

41 Note too the scope for the term 'environment' to be employed as either a passive or an active term, as discussed above. It 'constrains' development, it 'selects' some developments over others, but it is the 'context' or 'background' against which developments are introduced.

42 J. M. Balkin, Cultural Software: A Theory Of Ideology (1998). See also Dennett, n. 15 above. For a similar account of legal evolution in Lamarckian as opposed to Darwinian terms, see Roe, n. 22 above, 665.

43 The 'pattern of use' of these metaphors may usefully be termed a rhetoric. See Archer, n. 6 above.

44 Dworkin, n. 34 above at 1737, n. 76.

45 F. Fukuyama, The End of History and The Last Man (1992) 48.

46 Rose, Darwin's Spectre: Evolutionary Biology in the Modern World (1998) 81.

47 Elliott, n. 22 above, 600. See Ruhl, 'Complexity Theory as a Paradigm for the Dynamical Lawand-Society System: A Wake-Up Call for Legal Reductionism and the Modern Administrative State' (1996) 45 Duke L] 849.

48 Gould, The Panda's Thumb: More Reflections in Natural History (1980) 128 and 29. See also H. Rose and S. Rose (eds.), Alas, Poor Darwin: Arguments Against Evolutionary Psychology (2000). For a powerful critique of efforts to justify existing legal arrangements as natural, even inevitable, products of evolu- tion, see Gordon, 'Critical Legal Histories' (1984) 36 Stan. L. Rev. 57.

49 K. Popper, Objective Knowledge: An Evolutionary Approach (1972) 195. Reductionism in science has produced 'more and more rules ... condensed into fewer, but more abstract, general principles. The ultimate goal of reductionist science, a Theory of Everything, aims to condense the entire universe into a single system of meta-meta- . . . -meta-rules': J. Cohen and I. Stewart, The Collapse Of Chaos (1994) 397.

50 See Brown, n. 16 above, 154.

51 For a defence of the view that there is a complex interaction between social processes and scientific practice and that all is too fuzzy and complex to predict because any interaction with the environment is so context-specific, see Levins and Lewontin, n. 4 above; Lewontin et al., n. 11 above; and Rose, n. 48 above.

$5^{2}$ Rorty (1999), n. 36 above, 266

53 Holmes, n. 28 above, 447.

54 S. J. Gould, Eight Little Piggies: Reflections In Natural History (1993) 152. 